\title{
Mateusz Świetlicki
}

\section{"It felt better to stay quiet" Miming as a Non-Verbal Way of Coping with Trauma in Kathy Kacer's Masters of Silence (2019)}

\begin{abstract}
This article analyzes Kathy Kacer's Masters of Silence (2019), a novel about Marcel Marceau - the renowned mime artist who during the war cooperated with the French Resistance - and two fictional Jewish siblings struggling with the trauma of losing their parents, anti-Semitism, and the suppression of identity in a Catholic convent in southern France. The author examines the narrative techniques used by Kacer, including the combination of fiction with history and some elements of the biography of Marceau, and demonstrates that she not only shares the next-generation memory of World War II with her young readers but also depicts nonverbal ways of coping with trauma as potentially effective and empowering. Whereas Kacer's indifference to historical dates may be connected to her determination to portray Marceau as an adolescent role model, the novel is a successful narrative about trauma and the Holocaust history, and the depiction of Marceau's acts of resistance does not overshadow the young protagonists who do not just quiver and follow the instructions of the adults but mainly try to gain agency.
\end{abstract}

Keywords: Holocaust, World War II, trauma studies, affect, Canadian literature, children's literature of atrocity

(C)2020 M Świetlicki. This is an Open Access article distributed under the terms of the Creative Commons Attribution-Noncommercial 3.0 Unported License (http://creativecommons.org/ licenses/by-nc/3.0/), permitting all non-commercial use, distribution, and reproduction in any medium, provided the original work is properly cited.

Citation: Barnboken - tidskrift för barnlitteraturforskning/Journal of Children's Literature Research, Vol. 43, 2020 http://dx.doi.org/10.14811/clr.v43.529 
Do not the most moving moments of our lives find us without words?

(Marcel Marceau, qtd. in Vernon)

Numerous North American books trying to make the Holocaust graspable for young readers have been published since the memory boom at the turn of the twenty-first century, making World War II, especially the Shoah, an essential part of contemporary children's and young adult literature (Dean-Ruzicka 14). While commercially successful and critically acclaimed novels like Lois Lowry's Number the Stars (1989) and Jane Yolen's The Devil's Arithmetic (1988) have become classics, narratives dedicated to previously untold stories, often written in multimodal narrative formats, are regularly released. Kenneth Kidd calls this type of texts "children's literature of atrocity" (121), whereas Jane Gangi uses the term "the literature of genocide for young people" (7). Interestingly, Kidd suggests that despite the difficulty to talk about war atrocities with children, "there seems to be consensus now that children's literature is the most rather than the least appropriate literary forum for trauma work" (119). Kathy Kacer is a particularly prolific Canadian children's literature author who has published more than twenty Holocaust remembrance books in the last two decades, yet has received surprisingly little scholarly attention. Whereas in a matter frequent in children's literature, most of Kacer's works contain significant historical inaccuracies, connecting with her protagonists may enable contemporary young readers to apprehend the traumatic experiences of the victims of World War II.

Sharing next-generation memory ${ }^{1}$ through accessible historical fiction is especially important considering that most survivors, witnesses, and bystanders of the Nazi atrocities are no longer alive, and $62 \%$ of Canadian Millennials and Generation $\mathrm{Z}$ do not know that 6 million Jews - including 1,5 million children - were killed during World War II. 22\% have never even heard about the Holocaust ("New Survey"). Such works of historical fiction go beyond the role of Holocaust remembrance tools, though. After all, as Dominick LaCapra maintains, "[t]he role of empathy or empathetic unsettlement in the attentive secondary witness ... entails a kind of virtual experience through which one puts oneself in the other's position while recognizing the difference of that position and hence not taking the other's place" (78). Reading about past traumas can not only generate empathy in young readers but also help them better understand the dangers of the globally rising nationalist sentiments and anti-Semitism (Brown; "Experiences and Perceptions"). 
Additionally, as Eric Tribunella contends in his analysis of American children's literature, reading about geographically and historically distant atrocities has the potential to inoculate contemporary readers against modern-day traumas or painful experiences, such as the loss of parents (104). While Tribunella argues that the pattern he examines is particularly revealing of the production of American identity, I believe this perspective to be relevant also in the context of non-American children's literature. After all, "children's literature of atrocity" is a worldwide phenomenon, present not only in the Anglophone world, as there have been books about various war atrocities published in many languages in Western and non-Western cultures. For example, in her analysis of Polish Holocaust-themed children's books, Małgorzata Wójcik-Dudek concurs that by identifying with the experience of the protagonists, young readers can become more empathetic (223). Protagonists of many such books suffer from a traumatic loss and consequently learn to accept it using various coping strategies. In my examination of Kacer's Masters of Silence (2019) I demonstrate how mime, a non-verbal performance art rarely used in children's literature, can be used as an effective tool in working through trauma. After all, "[i]t is our body as a whole which has this power of resonating with the world" (Rolnik). While trauma "fractures the self, and punctures memory and language" (Schwab 42), I agree with Roni Natov who asserts that it "disrupts coherence" but "creating narrative restores it" (59). I also concur with Michael Rothberg who contends that trauma is "perhaps best thought of not as any kind of singular object." He focuses on studying how "the problem of individual psychic suffering became 'tangled up' with an array of the larger problems of modernity, including ... war" (xi, qtd. in Natov 85).

Masters of Silence, the second novel in Kacer's Heroes Quartet series², is about Marcel Marceau - the renowned mime artist who during the war cooperated with the French Resistance - and two fictional Jewish siblings struggling with the loss of their parents, anti-Semitism, and the suppression of identity in a Catholic convent in southern France. Studying the narrative techniques used by Kacer, such as combining fiction with history and the biography of Marceau, and having two child focalizers, I demonstrate that she not only shares the next-generation memory of World War II with her young readers but also depicts non-verbal ways of working through trauma as potentially effective and empowering. Analyzing the novel, I show that Henry, the traumatized protagonist, matures and learns to express himself by practicing the art of mime and creating a fragmented narrative in his journal. 


\section{Irrevocable Loss of Parents and Identity}

As a scholarly field in humanities, trauma studies emerged in the second half of the twentieth century as the aftermath of war atrocities, most importantly the Holocaust. Methodologically it was rooted in deconstruction and psychoanalysis, especially the reinterpretations of Sigmund Freud's and Jacques Lacan's seminal works. Leading trauma theorist Cathy Caruth argues that one has no control over trauma, which is not "the simple illness of a wounded psyche" as it is directly connected to narration: "it is always the story of a wound that cries out, that addresses us in the attempt to tell us of a reality or truth that is otherwise not available" (4). Yet, as she argues, trauma disobeys coherent narrative formats. Building on her theory LaCapra distinguishes between "working through" and "acting out" trauma. In the former, "one is able to distinguish between past and present and to recognize something as having happened to one (or one's people) back then which is related to, but not identical to here and now" (66). On the contrary, "[i]n acting out the past is performatively regenerated or relived as if it were fully present rather than represented in memory and inscription, and it hauntingly returns as the repressed" (70). While LaCapra's distinction assumes that trauma has to be set in past events, I believe that his terminology can be used in broader contexts, such as the analysis of Kacer's historical books, especially Masters of Silence.

The novel, addressed to children aged 9-12, tells the story of Helen and Henry Rosenthal, Jewish siblings from Frankfurt, Germany, age fourteen and ten, who during World War II are put in a Catholic convent in southern France by their mother who wants to save them from the Nazis. Pius XII, who was Pope 1939-1958, never publicly condemned killing Jews, believing communism to be a greater threat than Nazism (Phayer xii-xiii). Still, in occupied territories, such as France or Poland, some Catholic priests and nuns saved Jewish children, frequently teaching them prayers and asking them to behave like Catholic children ("WW2: The Nun;" Snyder 292-295). Accordingly, while many other children living in the convent in Kacer's novel are also Jewish, they all have to follow the same customs and pretend to be Catholic. To fit in and survive, the protagonists, both blond, Aryan-looking and bilingual, are asked to disown their identity by using new names - Claire and Andre Rochette (Kacer 31).

This seems more difficult for Henry, who, right after his mother leaves, stops speaking, silently coping with the irreversible loss of his parents and home while trying not to forget his real identity. As the 
Nazi occupation eventually comes to France, after a few months in the convent, the children escape to Switzerland with the help of the nuns and Marceau, a teenage mime artist they befriend. The novel quite successfully introduces young readers to the theme of World War II without being completely misleading. Still, it contains several historical inaccuracies, such as the fact that Kacer begins the novel in April 1940 and as soon as the protagonists arrive at the convent, a nun instantly refers to the government of Marshal Philippe Pétain, which collaborated with the Axis but took effect a few months later. The descriptions of incidents of Nazis searching for Jews in France before Hitler invaded the country on May 10 are also incorrect, as well as some biographical details concerning Marceau, such as the exaggeration of the role mime played in his collaboration with the French Resistance and several references to his famous post-World War II acts.

While Masters of Silence, the second volume in Kacer's series dedicated to little known World War II heroes, can be read as a tribute to Marceau, a historical figure, it is also a book about the coping strategy of the protagonist, a traumatized child. Kacer effectively combines the story of trying to work through trauma with the biography of Marceau, who is widely regarded as the most famous and critically acclaimed mime artist of the twentieth century and whose career lasted for over sixty years ${ }^{3}$. Born Marcel Mangel (1923-2007), the son of Polish Jews, during the Nazi occupation of France, together with his brother Alain he adopted a new last name as a tribute to François Séverin Marceau-Desgraviers, a general of the French Revolution. He is mostly remembered as Bip the Clown, but during World War II he cooperated with the French Resistance in Limoges. Saving countless children from concentration camps by helping them escape to Switzerland, sometimes he kept them quiet by using mime, a fact Kacer used as a central part of the novel's plot. Eventually Marceau joined the French Army after the liberation of Paris, during which he gave his first big performance to the troops. After the war, he perfected the art of mime and in 1947 created his alter ego, Bip the Clown (Vernon). As some critics argued, acting without words Marceau could achieve "in less than two minutes what most novelists cannot do in volumes" (Fellowes). In an 1987 interview with CBS, Marceau referred to mime as "art of silence," adding that it "speaks to the soul, like music, making comedy, tragedy, and romance, involving you and your life. [...] creating character and space, by making a whole show on stage - showing our lives, our dreams, our expectations" (qtd. in "Marcel Marceau Remembered"). 
In Masters of Silence the art of mime speaks to the soul of Henry, the traumatized protagonist. When Henry is introduced, he is portrayed angrily crying and screaming, desperately clinging to his mother, whom he does not want to leave, and then swiftly falling silent and going "limp as a rag doll" (Kacer 7). From that moment on the boy stops talking, and his sister thinks it is "worse to see him this way" because "shouting and begging had meant that he was fighting. Now he looked like a broken animal" (7). His behavior is not surprising, as trauma has an affective/emotional nature, connected with anger and fear (Pollock 50-52). Affects/emotions are also frequently associated with sound and silence, as shame and fear often cause silence, while anger causes the opposite reaction, particularly in children who have not been trained to control it (Ferens).

Henry displays many typical traumatic symptoms, including problems with building new relationships and social interactions at the convent, anxiety, aggression, and helplessness (Lanktree and Briere 6). Each chapter of the third-person novel describes the feelings and thoughts of either Henry or Helen. While the boy is compared to a lifeless rag doll and a broken animal by his sister, he is full of emotions: fear, anger, and sadness. Before becoming silent, Henry is angry and tries to use crying to make his mother stay: "He has thought that maybe, if he screamed long enough and loud enough, she would take him from this strange and spooky place," the narrator says (Kacer 11). Eventually the boy stops screaming, as it finally hits him that he cried and screamed when his father was arrested, so this time there is "no use yelling anymore" and it is "better to say nothing" (14). Instead of talking to his sister and trying to express his emotions, traumatized Henry hides them and stops talking - " [i]t felt as if something inside of him had died, dried up like a plant that had been yanked from the soil," his sister thinks (15). Helen and the nuns seem to treat Henry's silence as an indication of defeat, yet the boy is not passive. Helen's chapters show that she is not only worried about her younger brother's silence while trying to cope with her own emotions, but also that Henry previously suffered from similar silent modes after being bullied by anti-Semites in Germany. The one person who was able to soothe him was their absent mother (18).

Tribunella argues that irreversible loss "is experienced as a trauma" and "children's literature turns time and again to that which is traumatic as a way of provoking or ensuring the development of children" (xi). It is worth noting that Henry's anger is not only the consequence of the loss of his parents, but also the experience of antiSemitism and the necessity to symbolically deny his Jewishness. Af- 
ter all, "the sources of many kinds of anger are ideological and institutional" (Kim 4). When other boys at the convent talk about Henry and his family, the boy gets mad (Kacer 88-89) and attacks the one who implies that Henry's father must be dead, a possibility Henry rejects (90). Albert, Helen's new friend, who eventually leaves the convent with the siblings, stops the fight and talks to Henry, trying to soothe him (92). The boy's anger is replaced with sadness. Henry cannot leave his bed because "sadness came in waves, sometimes growing so strong that he thought his heart would explode" (86). This feeling is not only provoked by the fact that the boy is missing his parents whom he will probably never meet again, but also the fact that he is forced to pretend to be someone he is not. Henry later realizes that he is not the only one who feels such emotions - other children in the convent seem to be struggling with similar issues. Still, he struggles to connect with them.

When the boy receives a letter from his mother, instead of helping him, it provokes the opposite reaction as he feels "himself pulled down into that deep black hole where his mind had been living for such a long time, ever since his mother had left him here with Helen" (Kacer 133). As Henry feels abandoned, the letter and the memories it triggers expose "a vault of feelings that he had tried to push away or keep so tightly bottled up that they didn't overwhelm him" (138). The description of Henry's sadness after having experienced traumatic loss is one of melancholia that is frequent in children's Holocaust literature, which, as Tribunella notes, "makes use of melancholia as a trope for representing what many consider unrepresentable or too sacred for use as fodder for lessons" (125).

Despite remaining melancholic, silent, and struggling with the loss of his parents and identity, Henry learns how to communicate non-verbally with Helen. When Nazi soldiers approach the siblings in the shop they go to with Sister Agnes, it is Helen who almost forgets about their new, Catholic identity (Kacer 59). Remaining silent, Henry tugs his sister when she is about to say his real, Jewish name (61). Later he is shocked that Helen understood his intentions and thinks "[s]o, she does understand after all. [...] She knows! She understood what he had done. That was most important" (69). At first, Helen and the nuns try to make Henry speak, but the boy resists, feeling that "it felt better to stay quiet" because "keeping everything inside was better than letting it all out" (40). Henry decides that "[h]e would talk again when the time was right" and compares the role of his silence to the one the convent plays for Jewish children, saying that "he was harboring his feelings inside of him, protecting them, the way the 
children were protected here" (40). Though he understands that his sister is sad, the boy is incapable of helping her before dealing with his own emotions first. "Staying quiet was still better than talking, at least for now," he believes (109). Although he does not start communicating verbally with Helen until he needs her help, Henry knows that his sister understands his body language and depends on her.

Whereas Helen also has to cope with her own traumatic loss, unlike Henry, being four years older, she tries to control her emotions and finds it less difficult to assimilate. Despite initial problems with talking about herself caused by her mother's instruction to stay secretive about her identity, she quickly adjusts to the new situation. Although tears pool in Helen's eyes when she comes to the convent, the girl does not cry and tries "to be strong for whatever she was facing here" (Kacer 17). While she is constantly worried about her younger brother, Helen also has continuous nightmares and feels bullied by Sister Agnes, one of the nuns who is trying to make sure that the girl follows all of the rules and frequently punishes her for even minor acts of disobedience. The chapters presenting Helen's perspective are mainly supposed to provide more details on Henry and his silence, but they show that the girl also uses silence as a protective mechanism. She observes her brother and knows about the friendship between Henry and the clown, as well as about Henry's journal, but does not say anything. Helen also secretly keeps the photographs of her and Henry's parents. While she also thinks that maybe "at times, silence was better than talking" (181), unlike her brother, the girl befriends other children and deals with her own emotions by talking to Albert and Michelle. Later she also befriends Marceau who tells her about the role Charlie Chaplin, a figure some readers may be familiar with, played in his fascination with mime. ${ }^{4}$

\section{Non-Verbal Ways of Working through Trauma}

Henry starts working through his trauma by writing and drawing, and it is the non-verbal ways of expression that benefit him the most. Writing about trauma helps to "break the cycle repeatedly spinning itself out in the conscious or unconscious" because "[ $t$ ]he reader bears witness" (Natov 58). Notably, both psychologists and therapists agree that imaginative expression can help children cope with trauma and may preclude an emotional shutdown (Edgar-Bailey and Kress 161-163). The kind Sister Cecile, who later turns out to be a young Jewish woman in hiding, gives Henry a journal, thinking that it may help him try to express himself. After all, "[a]s healing 
may take time, creating a story, drawing, or other art form suggests ways of acknowledging and containing it" (Natov 60). While Henry believes that keeping a diary is for girls, mostly because Helen used to keep one back in Frankfurt, he calls his "a code book" (Kacer 37). Instead of creating a chronological, cohesive narrative, Henry repeatedly writes down his own name and crosses the new, French one out, additionally drawing the Star of David, the symbol of his real, suppressed identity, next to it. The boy's chaotic way of writing symbolizes his mental confusion.

Eventually Henry starts thinking that writing could actually help him, but as he has to keep the book hidden and can write only when he is on his own, this potential is limited. The boy writes down a list of things that could make him feel better and comes up with one called "[t]hings I would do if I was home right now" (Kacer 104). Compiling the list, he recalls his experiences in Frankfurt, such as the instances of anti-Semitism, the loss of the father, as well as his best friend, whose parents were Nazis. Despite what Helen and the nuns think, the boy seems emotionally present and aware of his circumstances.

After finally learning how to express himself non-verbally with the help of the journal and Marceau, who shows him the potential of mime and teaches him after every performance at the convent, Henry writes down in the code book that he is not only a Jewish boy named Henry Rosenthal, but also a mime artist (Kacer 135). By doing so, the protagonist symbolically attempts to reconstructs his lost identity. As Marceau befriends Henry, he gives the boy the nickname "Le muet" (126), the mute, and continues teaching him the art of mime. Although Henry struggles with accepting being Andre, he embraces his new identity of le muet, as it is not imposed, unlike the non-Jewish one. He not only performs with Marceau after his shows at the convent but also practices on his own when no one watches.

As Henry starts learning mime and continues writing in his code book, for a moment he considers not speaking again. The code book eventually becomes a source of problems, but also triggers Henry to finally speak up. The boy, late for a sport's class, leaves the book on his bed. Once it turns out that the Nazis are looking for Jews at the convent, he remembers the journal and wants to get it back and hide it, but is incapable of doing so on his own. Henry manages to go to the room and take the book, but then his sister finds him "clutching a notebook up against his chest so tightly that his knuckles were white" (Kacer 149). The boy wants Helen to look at the precious and secretive code book, but this time, occupied with the Nazis, she does 
not understand his body language. Finally, Henry has to speak. The raspy words he says are "[y]ou have to help me" (150). Helen and her friend Albert do so.

After reclaiming his voice, Henry ultimately has to bury the code book in the backyard. The Nazis do not find the journal, the indisputable evidence of Henry's Jewishness, as they arrest Sister Cecile who gave him the book. Everyone at the convent becomes silent, unable to express their feelings - this time it is Henry who speaks, as practicing mime and writing in the code book have helped him regain agency. The boy's gradual maturation throughout the novel is reminiscent of Tribunella's words that books about traumatic loss can "prompt the child's melancholic maturation through the introjection of what is disciplined and lost ... suggesting ultimately that it is childhood itself that must be lost" (125).

The growth of the protagonist of Masters of Silence is symbolically connected to the mime acts performed by Marceau - the bird and the lion tamer. When Henry and Helen are eventually forced to leave France for Switzerland, it turns out that Marceau is not only a performer, but also works for the French Resistance, helping children escape by forging documents and then traveling with them. During their trip, Marceau tells the protagonists that he is also Jewish and that similarly to Henry and Helen, he had to change his last name.

Mentions of the art of mime appear already at the beginning of the novel when Marceau is first called "the clown" by Helen's friend Michelle (Kacer 21). As the girl later adds, "[h]is real name is Marcel Marceau. We've just always called him the clown" (83), a clear reference to his later, post-World War II Bip the Clown persona. Unsurprisingly, other children at the convent quickly start comparing silent Henry to Marceau: "He's just like the clown... He doesn't talk either. But at least his shows are funny" (107). As the clown himself observes, Henry "understands the value of silence" (209). The boy, who does not connect with any children at the convent, becomes interested in mime even before the clown's first show: "A clown that doesn't talk? That sounded interesting" (107), he thinks. When Marceau finally appears in the novel, he turns out to be a teenager who "doesn't wear makeup or any costume" (112). Whereas Kacer does not provide a detailed visual description of Henry or Helen, Marceau is described as "young, seventeen, maybe eighteen at the most, with a full head of wiry, dark hair, a long nose, and intense eyes. He wore a tight, striped T-shirt and oversized overalls held up with suspenders. Finally, he raised his hand and the room grew quiet" (113-114). Though Marceau is a teenager, just a few years older 
than Helen, his portrayal clearly recalls the future image of Bip the Clown.

Notably, the first mime performance Helen and Henry see is the lion tamer (Kacer 114), which after the war became one of Marceau's most popular acts ("marcel marceau - liontamer"). After the performance, both Henry and Helen are enchanted, but it is the boy for whom the performance provokes a significant change: "His eyes were as round as two coins and he was beaming. Helen hadn't seen such absolute and total joy on his face since they had been together in Frankfurt as one complete family" (Kacer 116). Henry and the clown begin communicating using mimicry: "Henry [was] staring at the clown. The clown was staring back at Henry" (116). The protagonist starts repeating the clown's movements, and they instantly connect. Marceau teaches Henry another act, the bird, symbolically showing him the way to become free and work through his trauma and melancholia. This act is also the last one the protagonists see when they reach Switzerland - the place where they expect to find shelter.

Kacer intentionally incorporates into the novel two acts Marceau became famous for after the war. The bird and the lion tamer symbolize Henry's gradual maturation and the process of learning how to tame his own emotions and work through trauma. A direct reference to a lion appears in the letter that Henry receives from his mother. Trying to comfort her son, she writes Henry that as a little child, he was not afraid of the lion at the zoo. "You insisted that the lion didn't scare you. You were fearless," she recalls (Kacer 137). Initially after reading the letter, the boy starts crying as "[h]e didn't feel like a brave lion tamer at all, he thought. He felt so scared as the tiniest mouse" (138). In the context of the novel's historical and cultural background, the reference to the lion tamer may symbolize the biblical story of Daniel in the lions' den (The English Standard Version Bible, Daniel 6:22), when Daniel is saved by God because he "was found blameless before him" (Daniel 6:22). It is the first act the children see, but also the one that saves them from the Nazis during their escape to Switzerland. They are searched by soldiers who believe that Marceau is a scoutmaster teaching the children survival skills in the forest. When the Nazis are about to find the protagonists' real documents hidden in a sandwich, Henry once again freezes and loses his voice, this time involuntarily. Vulnerability, panic attacks, as well as the feeling of fear displayed by Henry, are typical symptoms of trauma (van der Kolk 403; Everett and Gallop 72). Seeing her brother's reaction, Helen starts performing the lion tamer act, and eventually, Henry, Albert, and Marceau join her. Together they feel fearless, 
and their performance distracts the soldiers who forget about the sandwich. While throughout the novel, Henry tries to work through trauma with the means of writing and mime, Kacer demonstrates that trauma is lingering, and the process of healing is not that easy.

\section{Conclusion}

The theme of an irreversible traumatic loss is a staple of "children's literature of atrocity." After all, as Natov argues, a narrative "in which a character becomes a witness to the pain of the traumatized young person and the journey where the child learns again how to trust can be illuminating and reassuring" (58). While usually mourning protagonists of such books use verbal coping strategies, in Masters of Silence Kacer displays the therapeutic potential of non-verbal, bodily ways of expression. Mime, a performance art perhaps underappreciated in our media-saturated times, emerges as Henry's most useful coping strategy, allowing the boy to resonate with the world.

As I have argued in this article, Masters of Silence can be read not as a simple semi-biography of Marceau but a narrative about the ways a child may try to use mime as a coping strategy in working through trauma, showing that there are no fixed ways of dealing with loss, anger, and sadness. Whereas Kacer's indifference to historical dates and details may be connected to her determination to portray Marceau as an adolescent role model, I believe that the depiction of his acts of resistance does not overshadow the young protagonists who do not just quiver and follow the instructions of the adults but try to gain agency. Frequently books for children about the Holocaust "are politically correct, but historically inaccurate, or ... 'spare the child' to such an extent that they are misleading" (Kokkola 168). Kacer, despite the aforesaid historical inaccuracies, not only celebrates Marceau but also allows the readers to reflect on anti-Semitism and the traumatic experiences of the Jewish children he saved. Although the novel ends with Henry and Helen overcoming some of their struggles and successfully reaching their destination, it is impossible to talk about a happy ending. The children are on their own and do not get to know their parents' fate - similarly to most real Holocaust survivors and young characters of World War II-themed children's fiction based on their experiences. 
Biographical information: Mateusz Świetlicki is an Assistant Professor at the University of Wroctaw (Institute of English Studies). His expertise is children's and YA literature and culture, gender and queer studies, as well as popular culture and film. Świetlicki is the author of more than 50 scholarly publications, including a book monograph, six co-edited volumes, as well as numerous articles and book chapters. He is currently working on a book project on next-generation memory in North American children's literature.

\section{Works Cited}

Brown, Sarah. "Growing Anti-Semitism in California and Globally." Pacific Council, 11 October 2019, http://www.pacificcouncil. org/newsroom/growing-anti-semitism-california-and-globally. Accessed 7 January 2020.

Caruth, Cathy. Unclaimed Experience: Trauma, Narrative and History. Baltimore and London, John Hopkins University Press, 1996.

Dean-Ruzicka, Rachel. Tolerance Discourse and Young Adult Holocaust Literature: Engaging Difference and Identity. New York, Taylor \& Francis Group, 2017.

Edgar-Bailey, Meredith, and Victoria E. Kress. "Resolving Child and Adolescent Traumatic Grief: Creative Techniques and Interventions." Journal of Creativity in Mental Health, vol. 5, no. 2, 2010, pp. 158-176, doi.org/10.1080/15401383.2010.485090.

Everett, Barbara, and Ruth Gallop. The Link between Childhood Trauma and Mental Illness: Effective Interventions for Mental Health Professionals. London, SAGE Publications, Inc., 2001.

"Experiences and Perceptions of Antisemitism - Second Survey on Discrimination and Hate Crime against Jews in the EU." FRA European Union Agency For Fundamental Rights, 10 December 2018, http:// www.fra.europa.eu/en/publication/2018/experiences-and-perceptions-antisemitism-second-survey-discrimination-and-hate. Accessed 7 January 2020.

Fellowes, Mave. "The Many Poses of Marcel Marceau." The Parisian Review, 9 July 2014, http://www.theparisreview.org/ blog/2014/07/09/the-many-poses-of-marcel-marceau. Accessed 7 January 2020. 
Ferens, Dominika. "Silence, Sound, and Fury: Affect Studies." XXXI Annual Conference of Polish Association for American Studies The Sound of Silence in American Literature, Culture and Politics, 24 October 2019, University of Opole, Poland. Keynote Address.

Gangi, Jane. Genocide in Contemporary Children's and Young Adult Literature: Cambodia to Darfur. New York, Routledge, 2014.

Kacer, Kathy. Masters of Silence. Toronto, Annick Press, 2019.

Kidd, Kenneth B. "'A' is for Auschwitz: Psychoanalysis, Trauma Theory, and the 'Children's Literature of Atrocity'." Children's Literature, no. 33, 2005, pp. 120-149, doi.org/10.1353/chl.2005.0014.

Kim, Sue J. On Anger: Race, Cognition, Narrative. Austin, University of Texas Press, 2013.

Kokkola, Lydia. Representing the Holocaust in Children's Literature. New York, Routledge 2003.

LaCapra, Dominick. Writing History, Writing Trauma. Baltimore, John Hopkins University Press, 2001.

Lanktree, Cheryl B., and John N. Briere. Treating Complex Trauma in Children and Their Families: An Integrative Approach. Los Angeles, SAGE publications, Inc., 2017.

Natov, Roni. The Courage to Imagine: The Child Hero in Children's Literature. London, Bloomsbury Academic, 2018.

"marcel marceau - liontamer." YouTube, uploaded by Feelinho, 20 June 2011, www.youtube.com/watch?v=t2nIF2ZO5jw.

"Marcel Marceau Remembered (CBS Sunday Morning)." YouTube, uploaded by despondentisthmus, 25 September 2007, www.youtube.com/watch?v=QbxNWmH6CAo.

"New Survey by the Azrieli Foundation and the Claims Conference Finds Critical Gaps in Holocaust Knowledge." Claims Conference, www.claimscon.org/study-canada. Accessed 7 January 2020.

Phayer, Michael. The Catholic Church and the Holocaust, 1930-1965. Bloomington, Indiana University Press, 2000.

Pollock, Griselda. "Art/Trauma/Representation." Parallax, vol. 15, no. 1, 2009, pp. 40-54, doi.org/10.1080/13534640802604372.

Rolnik, Suely. "The Geopolitics of Pimping." Translated by Brian Holmes. Transversal, October 2006, www.transversal.at/transversal/1106/rolnik/en?fbclid=IwAR040PxKR8HT3wWZZCqut-dV2il5nlplu3SaiwCoKJj9tuO7dXDTGFWI8pY. Accessed 7 January. 
Schwab, Gabriele. Haunting Legacies: Violent Histories and Transgenerational Trauma. New York, Columbia University Press, 2010.

Snyder, Timothy. Black Earth: The Holocaust as History and Warning. New York, Tim Duggan Books, 2015.

Świetlicki, Mateusz. "'You will bear witness for us': Suppressed Memory and Counterhistory in Marsha Forchuk Skrypuch's Hope's War (2001)." Anglica Wratislaviensia, vol. LVIII, 2020, pp. 83-95.

The English Standard Version Bible: Containing the Old and New Testaments with Apocrypha. New York, Oxford University Press, 2009.

Tribunella, Eric L. Melancholia and Maturation: The Use of Trauma in American Children's Literature. Knoxville, University of Tennessee Press, 2010.

Ulanowicz, Anastasia. Second-Generation Memory and Contemporary Children's Literature: Ghost Images. New York, Routledge, 2013.

van der Kolk, Bessel A. "Child Abuse \& Victimization." Psychiatric Annals, 2005, pp. 374-378.

Vernon, Diana. "Marcel Marceau, France's Most Memorable Mime." The Culture Trip, 26 October 2016, www.theculturetrip.com/europe/france/paris/articles/marcel-marceau-francesmost-memorable-mime. Accessed 7 January 2020.

Wójcik-Dudek, Małgorzata. Reading (in) the Holocaust: Practices of Postmemory in Recent Polish Literature for Children and Young Adults. Translated by Patrycja Poniatowska, Berlin, Peter Lang, 2020.

“WW2: The Nun Who Saved My Life." BBC News, 24 July 2020, www.bbc.com/news/av/world-europe-53512639/ww2-the-nunwho-saved-my-life. Accessed 2 August 2020.

\section{Notes}

1 Next-generation memory is a term based on Anastasia Ulanowicz's notion of second-generation memory. As I argue elsewhere, it "better reflects the potential of the transfer of memory, both described in children's books, where the givers of memories are often elderly family members, representatives of the third and fourth generations, as well as the one that can potentially occur between young readers and mnemonic narratives" (Świetlicki 86).

2 The Sound of Freedom was published in 2017 and Louder Than Words in 2020. 
3 Interestingly, Marceau also published two children's books, the Marcel Marceau Alphabet Book (1970) and the Marcel Marceau Counting Book (1971). A few years before his death, a children's photo book titled Bip in a Book (2001) was published by Stewart, Tabori \& Chang.

4 Bip the Clown, the alter ego Marceau adopted in 1947, was actually inspired by Chaplin's Little Tramp, whom he first saw at the age of five and became enchanted with his silent acting (Vernon). 